\title{
PENTACYCLIC TRITERPENES FROM FICUS PANDURATA HANCE. FRUIT
}

\author{
Amany Sayed Ahmed \\ Department of Pharmacognosy, Faculty of Pharmacy, Assiut University, Assiut, Egypt

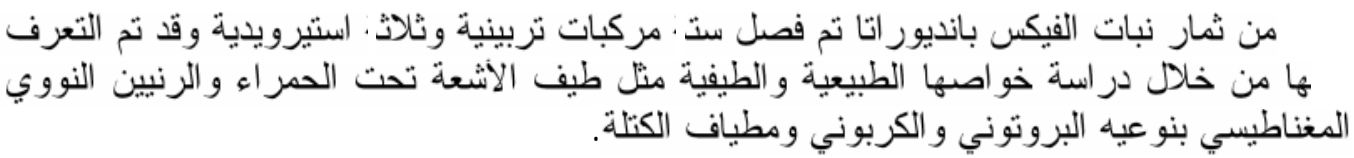 \\ From Ficus pandurata Hance fruits, six triterpenes and three sterols were isolated. The \\ structure of these compounds were elucidated using physical and spectral characters including \\ $I R,{ }^{l} \mathrm{H},{ }^{13} \mathrm{C}$-NMR including DEPT experiment and $M S$.
}

\section{INTRODUCTION}

Ficus is a large genus of trees or shrubs cultivated for their ornamental leaves and their edible fruits (F. sycomorus L.), while others for providing shade and as ornamental plants ${ }^{1-6}$. Ficus species has several biological activities ${ }^{7-11}$. Many phytoconstituents including triterpenes belonging to different skeleton and sterols were isolated and identified from different species of Ficus $^{12-25}$. Several Ficus species are indigenous to Egypt, others are recently introduced as Ficus pandurata. Ficus pandurata (the "Fiddle Leaf Fig") is one of the large leaved Ficus. In a previous study a variety of chemical constituents were isolated from the leaves and stem bark of Ficus pandurata ${ }^{26}$. In the present study triterpenes and sterols of the fruit were isolated and identified using different methods of analysis.

\section{EXPERIMENTAL}

\section{Instruments and apparatus}

1- Melting points (uncorrected) were determin-ed by electrothermal model 550 .

2- Schimadzu infra red-470 spectrophotometer (Japan) was used for measuring IR spectra as $\mathrm{KBr}$ discs.

3- ${ }^{1} \mathrm{H}$-NMR and ${ }^{13} \mathrm{C}-\mathrm{NMR}$ were recorded on JEOL-TNM-LA 500 spectrometers using TMS as an internal standard.

4- MS spectra were measured on SX102A.

5- Column chromatography was performed with silica gel 60 (E-Merck).
6- Precoated sheets of silica gel $60 \mathrm{G}_{254}$ (E-Merck) and RP-C ${ }_{18} \mathrm{~F}_{254}$ were used for TLC purposes.

7- The spots were visualized by UV lamp (254, $366 \mathrm{~nm}$, VL, LC, Marinc LavalecCodex, France) and sprayed with 10\% $\mathrm{H}_{2} \mathrm{SO}_{4}$.

8- Authentic samples were obtained from Department of Pharmacognosy, Faculty of Pharmacy, Assiut University.

9- Solvent systems used are: I- $n$-Hexane-EtOAc $(9: 1)$.

II- $\mathrm{CHCl}_{3}-\mathrm{MeOH}(9.5: 0.5)$

III- $\mathrm{CHCl}_{3}-\mathrm{MeOH}(9: 1)$

\section{Plant material}

Fruits of Ficus pandurata was collected in April-June 2008 from the front of Faculty of Pharmacy, Assiut University, Assiut.

The plant was kindly identified and authenticated by Prof. Dr. Salah EL-Naggar (Professor of Botany, Faculty of Science, Assiut University).

\section{Extraction and isolation}

The air dried powdered fruits $(3 \mathrm{~kg})$ of Ficus pandurata were exhaustively extracted with $\mathrm{MeOH}$ to yield $70 \mathrm{~g}$ of concentrated methanolic extract. Part of the concentrated combined methanolic extract $(60 \mathrm{~g})$ was successively fractionated with $n$-hexane, chloroform and ethyl acetate. 
The $n$-hexane soluble fraction $(25 \mathrm{~g})$ was chromatographed over silica gel C C using $n$ hexane-EtOAc gradiently (fractions $50 \mathrm{ml}$, each, were collected). Fractions eluted with $n$ hexane-EtOAc (95: 5) afforded compound 1, compound $\mathbf{2}$ and compound $\mathbf{3}$. Fractions eluted with $n$-hexane-EtOAc (9: 1) were purified by rechromatography over silica gel $\mathrm{CC}$ using $\mathrm{CHCl}_{3}-\mathrm{MeOH}$ gradiently. Subfractions eluted with $\mathrm{CHCl}_{3}-\mathrm{MeOH}$ (95: 5) gave compounds 4, 5 and 6. Fractions eluted with $n$-hexane-EtOAc (85: 15) were purified by rechromatography over silica gel column using $\mathrm{CHCl}_{3}-\mathrm{MeOH}$ gradients where sub-fractions eluted with $\mathrm{CHCl}_{3}-\mathrm{MeOH}$ (9: 1) gave compounds 7 and $\mathbf{8}$ respectively. The $\mathrm{CHCl}_{3}$ soluble fraction $(15 \mathrm{~g})$ was chromatographed over a silica gel column using gradient $\mathrm{CHCl}_{3}-\mathrm{MeOH}$ (fractions $50 \mathrm{ml}$, each, were collected). Fractions eluted with $\mathrm{CHCl}_{3}-\mathrm{MeOH}$ (9: 1) afforded compound 9, which was identified as $\beta$-sitosterol glucoside.

Compound 1: White amorphous powder, (15 $\mathrm{mg}$ ), IR $v \mathrm{~cm}^{-1}(\mathrm{KBr}): 1670$ and 1720. EI-MS $(\mathrm{m} / \mathrm{z}): 482 .{ }^{1} \mathrm{H}-\mathrm{NMR}\left(\mathrm{CDCl}_{3}, 500 \mathrm{MHz}\right), \delta$ : $0.78\left(3 \mathrm{H}, \mathrm{s}, \mathrm{CH}_{3}-25\right), 0.85\left(3 \mathrm{H}, \mathrm{s}, \mathrm{CH}_{3}-24\right)$, $0.89\left(3 \mathrm{H}, \mathrm{s}, \mathrm{CH}_{3}-28\right), 1.14(3 \mathrm{H}, \mathrm{d}, \mathrm{J}=7.0 \mathrm{~Hz}$, $\left.\mathrm{CH}_{3}-29\right), 1.22\left(3 \mathrm{H}, \mathrm{s}, \mathrm{CH}_{3}-23\right), 1.39(6 \mathrm{H}, \mathrm{s}$, $\left.\mathrm{CH}_{3}-26, \mathrm{CH}_{3}-27\right), 1.58$ (3H, s, $\left.\mathrm{CH}_{3}-30\right), 2.03$ $\left(3 \mathrm{H}, \mathrm{s}, \mathrm{CH}_{3}-32\right), 4.5(1 \mathrm{H}, \mathrm{dd}, \mathrm{J}=4.5,12.0 \mathrm{~Hz}$, $\mathrm{H}-3), 5.01(1 \mathrm{H}, \mathrm{s}, \mathrm{H}-21) .{ }^{13} \mathrm{C}-\mathrm{NMR}\left(\mathrm{CDCl}_{3}\right.$, $125 \mathrm{MHz}$ ) spectral data are listed in Table (1).

Compound 2 ( $\alpha$-amyrin): White needles (ethanol) $(10 \mathrm{mg})$, m.p. $202-204^{\circ} \mathrm{C}, \mathrm{IR} v \mathrm{~cm}^{-1}$ (KBr): 3455, 2945, 1375 and 1040.

Compound 3 ( $\beta$-amyrin): White needles (acetone), (25 mg), m.p. $185-187^{\circ} \mathrm{C}$, IR $v \mathrm{~cm}^{-1}$ (KBr): 3455, 2945, 1380 and 1037.
Compound 4 ( $\beta$-sitosterol): White needles (methanol), (15 mg), m.p. $134-136^{\circ} \mathrm{C}$.

Compound 5 (stigmasterol): Obtained as white crystalline needles (acetone), m.p. 168$170^{\circ} \mathrm{C}$. IR $v_{\max }(\mathrm{KBr}) \mathrm{cm}^{-1}: 3420(\mathrm{OH}), 2965$ $(\mathrm{C}-\mathrm{H})$ and $1636(\mathrm{C}=\mathrm{C})$.

Compound 6: White amorphous powder (10 $\mathrm{mg})$, IR $v \mathrm{~cm}^{-1}(\mathrm{KBr}): 3430,1670$. EI-MS $(\mathrm{m} / \mathrm{z}): 438,428,230,208 .{ }^{1} \mathrm{H}-\mathrm{NMR}\left(\mathrm{CDCl}_{3}\right.$, $500 \mathrm{MHz}), \delta: 0.79\left(3 \mathrm{H}, \mathrm{s}, \mathrm{CH}_{3}-25\right), 0.81(3 \mathrm{H}, \mathrm{s}$, $\left.\mathrm{CH}_{3}-24\right), 0.89$ (3H, s, $\left.\mathrm{CH}_{3}-28\right), 0.97$ (3H, d, J= $\left.7.0 \mathrm{~Hz}, \mathrm{CH}_{3}-29\right), 1.22\left(3 \mathrm{H}, \mathrm{s}, \mathrm{CH}_{3}-23\right), 1.39$ (6H, s, $\left.\mathrm{CH}_{3}-26, \mathrm{CH}_{3}-27\right), 1.49$ (3H, s, $\left.\mathrm{CH}_{3}-30\right)$, $3.5(1 \mathrm{H}, \mathrm{dd}, 4.5,12.0, \mathrm{H}-3), 5.01(1 \mathrm{H}, \mathrm{s}, \mathrm{H}-21)$, $5.11(1 \mathrm{H}, \mathrm{m}, \mathrm{H}-12) .{ }^{13} \mathrm{C}-\mathrm{NMR}\left(\mathrm{CDCl}_{3}, 125\right.$ $\mathrm{MHz}$ ) spectral data are listed in Table (1).

Compound 7: White amorphous powder, (15 $\mathrm{mg})$, IR $v \mathrm{~cm}^{-1}(\mathrm{KBr}): 3435$ and 1720. EI-MS (m/z): 484, 440 (2.2), 425 (3.6), 266 (4), 218 (7.9), 206 (4.2), 203 (9) and 133 (13.6). ${ }^{1} \mathrm{H}$ NMR $\left(\mathrm{CDCl}_{3}, 500 \mathrm{MHz}\right), \delta: 0.77\left(3 \mathrm{H}, \mathrm{s}, \mathrm{CH}_{3-}\right.$ 25), 0.86 (3H, s, $\left.\mathrm{CH}_{3}-24\right), 0.94\left(3 \mathrm{H}, \mathrm{s}, \mathrm{CH}_{3}-28\right)$, $0.97\left(3 \mathrm{H}, \mathrm{s}, \mathrm{CH}_{3}-29\right), 1.00$ (3H, s, $\left.\mathrm{CH}_{3}-23\right)$, $1.03\left(6 \mathrm{H}, \mathrm{s}, \mathrm{CH}_{3}-26, \mathrm{CH}_{3}-27\right), 1.23(3 \mathrm{H}, \mathrm{s}$, $\left.\mathrm{CH}_{3}-30\right), 2.07\left(3 \mathrm{H}, \mathrm{s}, \mathrm{CH}_{3}-32\right), 4.33,(1 \mathrm{H}, \mathrm{d}$, 14.0, H-3), $5.01(1 \mathrm{H}, \mathrm{m}, \mathrm{H}-2), 5.14(1 \mathrm{H}, \mathrm{m}, \mathrm{H}-$ 12). ${ }^{13} \mathrm{C}-\mathrm{NMR}\left(\mathrm{CDCl}_{3}, 125 \mathrm{MHz}\right)$ spectral data are listed in Table (1).

Compound 8: White amorphous powder, (10 $\mathrm{mg})$, IR $v \mathrm{~cm}^{-1}(\mathrm{KBr}): 3430$. EI-MS (m/z): 442, 427, 424 and $207{ }^{1} \mathrm{H}-\mathrm{NMR}\left(\mathrm{CDCl}_{3}, 500 \mathrm{MHz}\right)$,

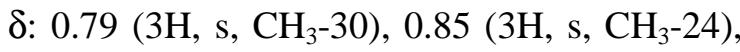
$0.90\left(3 \mathrm{H}, \mathrm{s}, \mathrm{CH}_{3}-28\right), 0.97\left(3 \mathrm{H}, \mathrm{CH}_{3}-29\right), 1.00$ (3H, s, $\left.\mathrm{CH}_{3}-26\right), 1.03$ (6H, s, $\left.\mathrm{CH}_{3}-23\right), 1.16$ $\left(3 \mathrm{H}, \mathrm{s}, \mathrm{CH}_{3}-25\right), 1.23\left(3 \mathrm{H}, \mathrm{s}, \mathrm{CH}_{3}-27\right), 3.28$ (1H, dd, 4.0, 14.0, H-3), 3.55 (1H, m, H-22). 
Table 1: ${ }^{13} \mathrm{C}-\mathrm{NMR}$ data of compounds $\mathbf{1 , 6 - 8}\left(\mathrm{CDCl}_{3}, 125 \mathrm{MHz}\right)$.

\begin{tabular}{|c|c|c|c|c|}
\hline \multirow{2}{*}{$\begin{array}{c}\text { Carbon } \\
\text { no. }\end{array}$} & \multicolumn{4}{|c|}{ Chemical shift } \\
\hline & $\begin{array}{l}\text { Compound } \\
\text { (1) }\end{array}$ & $\begin{array}{l}\text { Compound } \\
\text { (6) }\end{array}$ & $\begin{array}{l}\text { Compound } \\
\text { (7) }\end{array}$ & $\begin{array}{c}\text { Compound } \\
\text { (8) }\end{array}$ \\
\hline 1 & 39.85 & 38.7 & 40.6 & 38.6 \\
\hline 2 & 24.14 & 27.2 & 64.39 & 27.4 \\
\hline 3 & 82.0 & 78.3 & 80.59 & 77.7 \\
\hline 4 & 36.77 & 38.7 & 38.70 & 38.9 \\
\hline 5 & 59.0 & 55.2 & 58.99 & 54.9 \\
\hline 6 & 18.55 & 18.3 & 18.24 & 18.3 \\
\hline 7 & 33.67 & 32.9 & 32.60 & 33.2 \\
\hline 8 & 41.0 & 40.0 & 40.91 & 42.7 \\
\hline 9 & 51.3 & 47.7 & 47.65 & 48.4 \\
\hline 10 & 36.76 & 36.9 & 36.60 & 36.9 \\
\hline 11 & 22.34 & 23.3 & 23.92 & 23.8 \\
\hline 12 & 27.55 & 121.7 & 121.22 & 28.7 \\
\hline 13 & 37.81 & 140.6 & 144.00 & 132.8 \\
\hline 14 & 43.4 & 42.0 & 42.07 & 43.8 \\
\hline 15 & 27.2 & 28.7 & 29.29 & 25.1 \\
\hline 16 & 28.34 & 26.6 & 26.27 & 33.0 \\
\hline 17 & 54.1 & 55.9 & 32.26 & 40.2 \\
\hline 18 & 45.2 & 45.1 & 47.65 & 133.5 \\
\hline 19 & 36.82 & 35.6 & 45.0 & 37.9 \\
\hline 20 & 167.7 & 165.3 & 31.25 & 32.2 \\
\hline 21 & 125.0 & 125.9 & 34.55 & 43.5 \\
\hline 22 & 199.70 & 202.5 & 37.75 & 78.8 \\
\hline 23 & 28.2 & 28.5 & 28.09 & 28.1 \\
\hline 24 & 16.50 & 16.4 & 15.72 & 15.6 \\
\hline 25 & 17.66 & 15.1 & 14.80 & 16.3 \\
\hline 26 & 16.76 & 17.0 & 16.86 & 18.8 \\
\hline 27 & 15.52 & 15.5 & 26.60 & 20.4 \\
\hline 28 & 17.55 & 17.55 & 28.66 & 16.7 \\
\hline 29 & 21.43 & 21.30 & 34.42 & 25.1 \\
\hline 30 & 20.60 & 20.50 & 23.7 & 32.2 \\
\hline 31 & 171.0 & - & 174.00 & - \\
\hline 32 & 21.42 & - & 22.69 & - \\
\hline
\end{tabular}

\section{RESULTS AND DISCUSSION}

Phytochemical study of Ficus pandurata fruits resulted in the isolation and identification of nine compounds.

Compounds 2, 3, 4, 5 and 9 were identified as $\alpha$-amyrin, $\beta$-amyrin, $\beta$-sitosterol, stigmasterol and $\beta$-sitosterol-3-O- $\beta$-glucoside respectively...by comparing their physical and chromatographic characters with authentic samples.
Compound 1 was obtained as amorphous powder, which gave a positive LiebermannBurchard's test for triterpenes. Its IR displayed absorption bands attributed to conjugated ketone group $\left(1670 \mathrm{~cm}^{-1}\right)$ and acetoxyl group $\left(1720 \mathrm{~cm}^{-1}\right)$. The EI-MS spectrum of compound 1 showed $\left[\mathrm{M}^{+}\right]$at $\mathrm{m} / \mathrm{z}$ 482. The molecular formula was deduced to be $\mathrm{C}_{32} \mathrm{H}_{50} \mathrm{O}_{3}$ from the MS, ${ }^{1} \mathrm{H}-, \quad{ }^{13} \mathrm{C}-\mathrm{NMR}$ including DEPT experiments. 
The ${ }^{1} \mathrm{H}-\mathrm{NMR}$ gave signals due to eight methyl groups, one is doublet and seven are singlets at $\left(\delta_{\mathrm{H}} 0.78,0.85,0.89,1.14,1.22,1.39\right.$ (2 Me) and 1.58), in addition to an acetyl group. In the low filed region, an olefinic proton $\left(\delta_{\mathrm{H}} 5.01\right)$ vicinal to carbonyl group and a proton adjacent to acetyl group $\left(\delta_{\mathrm{H}} 4.5\right)$ were observed. These data are similar to a taraxstane triterpene previously isolated from the same plant ${ }^{26}$. The ${ }^{13} \mathrm{C}-\mathrm{NMR}$ spectrum of compound $\mathbf{1}$ had thirty two carbon signals including two olefinic signals ( $\delta_{\mathrm{C}} 167.7$ and 125.0$)$ as singlet and doublet respectively, one oxygenated carbon at $\delta_{\mathrm{C}} 82.0$ and one conjugated carbonyl carbon at $\delta_{\mathrm{C}} 199.7(\mathrm{C}-22)$. Comparing the ${ }^{13} \mathrm{C}-\mathrm{NMR}$ data of compound $\mathbf{1}$ with those reported for $3 \beta$-acetoxy-20-taraxasten-22-one, they seemed to be identical. So compound 1 was identified as $3 \beta$-acetoxy-20-taraxasten-22one and it was isolated previously from Ficus pandurata Hance leaves and stem bark ${ }^{26}$.

Compound 6 gave a positive LiebermannBurchard's test for triterpenes, it showed hydroxyl group $\left(3430 \mathrm{~cm}^{-1}\right)$ and conjugated ketone group $\left(1670 \mathrm{~cm}^{-1}\right)$ in the IR spectrum. The molecular formula was deduced to be $\mathrm{C}_{30} \mathrm{H}_{46} \mathrm{O}_{2}$ from the MS, ${ }^{1} \mathrm{H}-,{ }^{13} \mathrm{C}-\mathrm{NMR}$ including DEPT experiments.

The ${ }^{1} \mathrm{H}$-NMR showed seven singlet methyl groups at $\delta_{\mathrm{H}} 0.79,0.81,0.89,1.22,1.39,1.49$ and 1.60 and one doublet methyl group at $\delta_{\mathrm{H}}$ $0.97(\mathrm{~d})$, one oxygenated methine proton at $\delta_{\mathrm{H}}$ $3.5(1 \mathrm{H}, \mathrm{dd}, \mathrm{J}=4.5,12 \mathrm{~Hz})$, in addition to two olefinic protons, one vicinal to a carbonyl group $\delta_{\mathrm{H}} 5.01(1 \mathrm{H}, \mathrm{s}, \mathrm{H}-21)$ and the second at $\delta_{\mathrm{H}} 5.11(1 \mathrm{H}, \mathrm{m}, \mathrm{H}-12)$. When compared with compound 1, it was suggested to be a taraxstane triterpene. The two signals appeared in the spectrum of compound $\mathbf{1}$ at $\delta_{\mathrm{C}} 171.0$ and 21.42 for the acetyl group were disappeared in the spectrum of compound $\mathbf{6}$, also the signals for C-2 and C-4 in compound $\mathbf{6}$ were downfield shifted by 3.06 and $1.93 \mathrm{ppm}$ respectively, while the signal for C-3 (in compound 6) was upfield shifted by $3.7 \mathrm{ppm}$ confirming the absence of the acetate group from $\mathrm{C}-3$ position of compound $\mathbf{6}$. The IR spectrum also showed the disappearance of the acetoxyl group (at $1720 \mathrm{~cm}^{-1}$ ). In the other hand another olefinic proton was appeared in compound 6 at $\delta_{\mathrm{H}} 5.11$ (1H, m, H-12) by comparing with compound 1 and other similar triterpenes, indicating the presence of a second double bond in this compound. The location of the second double bond must behave one doublet carbon $\left(\delta_{\mathrm{C}} 121.7\right)$ and another singlet one $\left(\delta_{\mathrm{C}} 140.0\right)$. The EI-MS of compound 6 exhibited peaks due to the characteristic fragmentation at $\mathrm{m} / \mathrm{z} 230$ (D/E) and 208 (A/B ring) by retro-Diels-Alder fission supported this structure clearly, the fragment at $\mathrm{m} / \mathrm{z} 230$ indicating a C-12/C-13 double bond (Fig. 2). The peak at $\mathrm{m} / \mathrm{z} 420$ is corresponding to the loss of water from the molecule, indicating the presence of $\mathrm{OH}$ group in the structure. The $\beta$ configuration of the $\mathrm{OH}$ group was assigned according to the fact that the proton appeared as $d d$, where the large coupling constant $(\mathrm{J}=12.0)$ established an axial configuration of this proton and $\beta \mathrm{OH}$ group ${ }^{27}$. Therefore compound 6 was identified as $3 \beta$ hydroxy-12, 20-taraxastdiene-22-one, and this is the first report for its isolation from genus Ficus.

Compound 7 was obtained as amorphous powder. The IR spectrum showed the presence of hydroxyl and acetoxyl groups absorption bands at 3435 and $1720 \mathrm{~cm}^{-1}$. The molecular formula of compound 7 was deduced to be $\mathrm{C}_{32} \mathrm{H}_{52} \mathrm{O}_{3}$ from the MS, ${ }^{1} \mathrm{H}-,{ }^{13} \mathrm{C}-\mathrm{NMR}$ and DEPT experiment. The ${ }^{1} \mathrm{H}-\mathrm{NMR}$ spectrum showed the presence of eight singlet methyls, one olefinic proton $5.14(1 \mathrm{H}, \mathrm{m}, \mathrm{H}-12)$, two oxymethine protons $\delta_{\mathrm{H}} 4.33(1 \mathrm{H}, \mathrm{d}, \mathrm{J}=14.0$, $\mathrm{H}-3)$ and $5.01(1 \mathrm{H}, \mathrm{m}, \mathrm{H}-2)$ and one acetyl group $2.07\left(3 \mathrm{H}, \mathrm{s}, \mathrm{CH}_{3}-32\right)$. The ${ }^{13} \mathrm{C}-\mathrm{NMR}$ spectrum revealed the existence of 32 carbons ascribable to 9 methylenes, 9 methyls, 6 methines and 8 quaternary carbons by DEPT spectrum. Both the ${ }^{1} \mathrm{H}$ - and ${ }^{13} \mathrm{C}-\mathrm{NMR}$ depicted data typical of a triterpene of oleanane or ursane skeleton with a double bond between C$12 / \mathrm{C}-13$ and one acetyl group ${ }^{28}$. This was further supported by the characteristic retro Diels-Alder cleavage of $\mathrm{C}-12$ double bond pentacyclic triterpene skeleton leading to $\mathrm{m} / \mathrm{z}$ $218\left(\mathrm{C}_{16} \mathrm{H}_{26}, 7.9\right)$ and $266\left(\mathrm{C}_{16} \mathrm{H}_{26} \mathrm{O}_{3}, 4\right)$, thus indicating that the hydroxyl group and the acetyl group were present in the rings $\mathrm{A} / \mathrm{B}$ of the molecule ${ }^{29}$ (Fig. 2). The olean-12-ene was inferred from the chemical shifts of $\mathrm{C}-12 .\left(\delta_{\mathrm{C}}\right.$ $121.2)$ and $\mathrm{C}-13 .\left(\delta_{\mathrm{C}} 144.0\right)^{30}$. The signal at $\delta_{\mathrm{H}}$ 4.33 was assigned for the H-3 proton where the large coupling constant $(\mathrm{J}=14.0)$ established an axial configuration of this proton and $\beta$ acetyl group. Comparing the chemical shifts of each 
carbon with those reported for $\beta$-amyrin, it was suggested that the acetyl group was located at $\mathrm{C}-3$ and the hydroxyl group at C-2. So, compound 7 was identified as $2 \beta$ - hydroxyl- 3 $\beta$-acetoxy $\beta$-amyrin, and this is the first report for its isolation from genus Ficus.

Compound $\mathbf{8}$ was obtained as amorphous powder. The IR spectrum showed the presence of hydroxyl group $\left(3430 \mathrm{~cm}^{-1}\right)$. The molecular formula of compound $\mathbf{8}$ was deduced to be $\mathrm{C}_{30} \mathrm{H}_{50} \mathrm{O}_{2}$ from the MS, ${ }^{1} \mathrm{H}-,{ }^{13} \mathrm{C}-\mathrm{NMR}$ and DEPT experiment. The MS spectrum showed $\left[\mathrm{M}^{+}\right]$at $\mathrm{m} / \mathrm{z}$ 442. The ${ }^{1} \mathrm{H}-\mathrm{NMR}$ spectrum showed the presence of 8 singlet tertiary methyl signals $\delta_{\mathrm{H}} 0.79,0.85,0.90,0.97,1.00$, $1.03,1.16,1.23$, the signal at $\delta_{\mathrm{H}} 3.28$ was assigned for the $\mathrm{H}-3$ proton where the large coupling constant $(\mathrm{J}=14.0 \mathrm{~Hz})$ clearly established an axial $(\alpha$ configuration of this proton and $\beta$-hydroxyl group. The ${ }^{13} \mathrm{C}-\mathrm{NMR}$ spectrum showed 30 carbon signals i.e. 8 singlets, 4 doublets, 10 triplets and 8 quartets.
The signals at $\delta_{\mathrm{C}} 77.7$ and $\delta_{\mathrm{C}} 78.8$ were assigned for two oxygen bearing carbons, C-3 and C-22 respectively, this was confirmed by the presence of fragment at $\mathrm{m} / \mathrm{z} 207$ in the EIMS spectrum, which indicates that one hydroxyl group was present at rings $\mathrm{A} / \mathrm{B}$ of the molecule and the other at rings $\mathrm{D} / \mathrm{E}$. The peak at $\mathrm{m} / \mathrm{z} 424$ is corresponding to the loss of water from the molecule, indicating the presence of $\mathrm{OH}$ group (s) in the structure. The two olefinic signals at $\delta_{\mathrm{C}} 132.8$ and $\delta_{\mathrm{C}} 133.3$ as singlets supported the location of the double bond at $\mathrm{C}$ 13 and C-18 respectively ${ }^{31}$. The assignments of each carbon signal are cited in Table (1). Comparing the chemical shifts of each carbon with those reported for abrisopagenol $\mathrm{G}^{31}$, compound $\mathbf{8}$ was identified as $3,22 \beta$ dihydroxy-13 (18) oleanene.

According to the available current literatures compounds $\mathbf{6}$ and $\mathbf{7}$ are new compounds.<smiles>CC(=O)OC1CCC2(C)C(CCC3(C)C2CCC2C4[C@H](C)C(C)=CC(=O)C4(C)CCC23C)C1(C)C</smiles>

Compound 1<smiles>CC(=O)OC1C(O)CC2(C)C(CCC3(C)C2CC=C2C4CC(C)(C)CCC4(C)CCC23C)C1(C)C</smiles>

Compound 7<smiles>CC1=CC(=O)C2(C)CCC3(C)C(=CCC4C5(C)CCC(O)C(C)(C)C5CCC43C)C2[C@H]1C</smiles>

Compound 6<smiles>CC1(C)CC2=C3CCC4C5(C)CCC(O)C(C)(C)C5CCC4(C)C3(C)CCC2(C)C(O)C1</smiles>

Compound 8

Fig. 1: Compounds isolated from Ficus pandurata Hance. 
<smiles>C=CC1=C(C)CCC2(C)C(=O)C=C(C)C(C)C1C2C</smiles>

\section{Compound 6}<smiles>C=CC1=C(C)CCC2(C)CCC(C)(C)CC12</smiles>

\section{Compound 7}

Fig. 2: Some important MS fragments of compound 6 and compound 7.

\section{REFERENCES}

1- L. H. Baily, "The Standard Cyclopedia of Horticulture", New York, the Macmillan Co., $11^{\text {th }}$ Edition, 1963, pp.1229-33.

2- P. Richard Lin. Wunder, "Flora of North America", Oxford University press, NC, 198 Madison Avenue, New York, 10016, 1997, pp. 388-89, 396-400.

3- C. R. Metcalf and L. Chalk, "Anatomy of Dicoteyledons", the Clarendon press, oxford, 11, 1950, pp. 1259-91.

4- L. H. Baily, "Mannual of Cultivated Plants", The MacMillan Co., New York, 1958, p.338.

5- M. P. Singh, M. P. Nayar, R. P. Nayar and R. P. Roy, "Text Book of Forest Taxonomy", Anmol publication PVT. Ltd, New Delhi-110002, 1994, pp. 446-50.

6- G. H. M. Lawrence, "Taxonomy of Vascular Plant", MacMillan Co., New York, 1962, pp. 462-64.

7- E. P. Lansky, H. M. Paavilainen, A. D. Pawlus and R. A. Newman, "Ficus spp. (fig): Ethnobotany and potential as anticancer and anti-inflammatory Agents", A Review, J. of Ethnopharmacology, 119, 195-213 (2008) and References cited therein.

8- O. Mousa, Vuorela P. Vuorela, J. Kiviranta, S. Abdel Wahab, R. Hiltunen, and H. Vuorela, "Bioactivity of certain Egyptian Ficus species". Ibid., 41, 71-76 (1994).

9- El. S. Abdel-Hameed, "Total phenolic contents and free radical scavenging activity of certain Egyptian Ficus species leaf samples", Food Chemistry 114, 12711277 (2009).

10- C. Ao, A. LI, A. A. El-zaawely, T. D. Yuan and S. Tawata, "Evaluation of antioxidant and antimicrobial activities of Ficus microcarpa", Food Control, 19 (10), 940-948 (2008).

11- R. K. Singh, S. Mehta, D. Jaiswal, P. K. Rai and G. Watal, "Antidiabetic effect of Ficus bengalensis aerial roots in experimental animals", J. of Ethnopharmacology, 123, 110-114 (2009). 
12- Y. H. Kuo, and Y. M. Chiang, "Five new taraxastane-type triterpenes from the aerial roots of Ficus microcarpa", Chem. Pharm. Bull., 47, 498-500 (1999).

13- N. V. Tuyen, D. S. H. L. Kim, H. S. Fong, D. D. Soejarto, T. -C. Khanh, M. V. Tri and L. T. Xuan, "Structure elucidation of two triterpenoids from Ficus fistulosa", Phytochemistry, 50, 467-469 (1998).

14- Y. Kuo and H. Lin, "Two novel triterpenes from the Leaves of Ficus microcarpa", Helvetica Chimica Acta, 87, 1071-1076 (2004).

15- Y. M. Chiang, J. Chang, C. Kuo, C. Chang and Y. Kuo, "Cytotoxic triterpenes from the aerial roots of Ficus microcarpa", Phytochemistry, 66 (4), 495-501 (2005).

16- Y. Chiang and Y. Kuo, "Novel triterpenoids from the aerial roots of Ficus microcarpa", J. Org. Chem., 67, 76567661, (2002).

17- Y. Chiang, J. Kuan Su, Y. Liu, and Y. Kuo, "New cyclopropyl-triterpenoids from the aerial roots of Ficus microcarpa", Chem. Pharm. Bull., 49 (5) 581-583 (2001).

18- H. M. P. Poumale, R. T. Kengap, J. C. Tchouankeu, F. Keumedjio, H. Laatsch and B. T. Ngadjui, "Pentacyclic triterpenes and other constituents from Ficus cordata (Moraceae)", Z. Naturforsch., 63B, 1335-1338 (2008).

19- Y.-M. Chiang and Y. H. Kuo, "New peroxy triterpenes from the aerial roots of Ficus microcarpa", J. Nat. Prod., 64, 436439 (2001).

20- Y. M. Chiang and Y. H. Kuo, "Taraxastane-type triterpenes from the aerial roots of Ficus microcarpa", ibid., 63, 898-901 (2000).

21- F. Sisay and B. Abeba, "Triterpene compounds from the latex of Ficus sur I.", Bulletin of the Chemical Society of Ethiopia, 19 (2), 307-310 (2005).
22- Y.H. Kuo and Y. M. Chiang, "Six new ursane- and oleanane-type triterpenes from the aerial roots of Ficus microcarpa", Chem. Pharm. Bull., 48 (5) 593-596 (2000)

23- H. A. A. Dafalla, "Studies on constituents of Ficus capensis (Thunb)". Pakestan J. Social Science, 3 (5), 751-754 (2005).

24- M. Parveen, R. M. Ghalib, S. H. Mehdi, S. Z. Rehman and M. Ali, "A new triterpenoid from the leaves of Ficus benjamina (var. comosa)", Natural Product Research. 23 (8), 729-736 (2009).

25- C. Y. Ragasa, E. Juan and J. A. Rideout, "A triterpene from Ficus pumzla", J. of Asian Natural Products Research, 1, 269275 (1999).

26- M. A. Ramadan, A. S. Ahmad, A. M. Nafady and A. I. Mansour, "Chemical composition of the stem bark and leaves of Ficus pandurata Hance", Natural Product Research, 23:13, 1218 -1230 (2009).

27- C. Peirs, N. Fabre, C. VM. Gao and I. Fouraste, "Triterpenoids from the aerial parts of Galega officinalis", Electronic J. of Natural Substance, 1, 6-11 (2006).

28- L.O.A. Mangura, S. O. Okwiri and P. Lemmen, "Oleanane-type tritepenes of Embelia schimperi leaves", Phytochemistry, 67, 2641-2650 (2006).

29- S. Hiradate, H. Yada, T. Ishii, N. Naoko, M. Ohnishi-Kameyama, H. Sugi, S. Zungsontipan and Y.Fujii, "Three plant growth inhibitory saponins from Duranta repens", ibid., 52, 1223-1228 (1999).

30- S. Bittner, A. K. Machocho, S. Grenberg, P. C. Kiprono, "Pentacyclic triterpenes from Embelia schimperi", ibid., 62, 573577 (2003).

31- J. Kinjo, K. Matsumoto, M. Inoue, T. Takeshita and T. Nohara, "A new sapogenol and other constituents in Abri Semen, the seeds of Abrus precatorius", Chem. Pharm. Bull., 39 (1), 116 (1991). 